\title{
Surgical treatment of brain metastases of lung cancer: retrospective analysis of 89 cases
}

Hidemitsu Nakagawa, Yoji Miyawaki, Toshiaki Fujita, Shigeki Kubo, Koji Tokiyoshi, Koichiro Tsuruzono, Ken Kodama, Masahiko Higashiyama, Osamu Doi, Toru Hayakawa

\begin{abstract}
The records of 89 patients who underwent surgery for solitary or multiple parenchymal brain metastases of lung cancer at the Osaka Center for Adult Diseases between 1978 and 1990 were reviewed with follow up until March 1992. The aim of this retrospective analysis was to identify prognostic features that were associated with a favourable outcome. The benefits of brain tumour surgery were evaluated in terms of the cause of death (brain metastasis, tumour in another organ, or treatment related) as well as the postoperative changes in functional state indicated by the Karnofsky scale. The overall mean survival time was 11.6 months, and the one and two year survival rates were $24 \%$ and $8 \%$. The brain lesion itself was the cause of death in only $19 \%$ of the patients; the other $81 \%$ died of systemic disease. Functional state improved after surgical excision of the brain tumour in $36 \%$, remained unchanged in $53 \%$, and worsened in $11 \%$. These data suggest that surgical intervention is beneficial for patients with parenchymal brain metastases. Variables significantly associated with a favourable prognosis included surgical excision of the primary lesion, adenocarcinoma as the histological diagnosis, the use of adjuvant treatment, especially chemotherapy, a preoperative score of over $80 \%$ on the Karnofsky scale, and metastasis confined to the brain with no extracranial metastatic foci or residual primary tumour. Additional but non-significant contributors to a good prognosis included age under 65 or 70 years, early tumour stage (stage 1), curative lung cancer surgery, a single metastatic brain tumour ( $v$ multiple lesions), a solid tumour ( $v$ cystic), and a supratentorial location of the brain metastasis. The disease free interval and the cerebrospinal fluid cytology were not significant prognostic factors. On the basis of these findings, it is concluded that the surgical removal of brain metastases of lung cancer should be undertaken if the primary tumour has already been removed whether or not there are extracranial metastases, and that postoperative chemotherapy should generally be given.
\end{abstract}

$(\mathfrak{F}$ Neurol Neurosurg Psychiatry 1994;57:950-956)
A general consensus has not yet been reached as to whether surgical resection or conservative treatment, particularly radiotherapy, ${ }^{1}$ is preferable for treating metastatic brain tumours. In general, surgical resection followed by radiotherapy is the most widely used approach for a solitary cerebral metastasis. ${ }^{23}$ A randomised trial by Patchell et al showed that the combination of surgery and irradiation was superior to irradiation alone. ${ }^{4}$ Moreover, an increase in long term survival after tumour excision has been reported by others. ${ }^{56}$

At the Osaka Center for Adult Diseases, our policy is to provide relatively aggressive treatment for patients with metastatic brain tumours. Our criteria for surgical treatment are reasonable stability of both the primary lesion and any metastases outside the brain and the expectation of a fairly high postoperative quality of life for at least two to three months. When the tumour is larger than a certain size (usually $1 \mathrm{~cm}$ ) and both improvement in neurological symptoms and prolongation of survival are anticipated, total excision is performed in a single operation. This applies even to multiple brain metastases (up to three) and metastases involving both hemispheres. Sometimes a multiple craniotomy is performed, and the patient's wishes and general condition are given full consideration.

The factors affecting the prognosis of patients with metastatic brain tumours have been considered in the medical literature, but these are complex and involve many variables, making it difficult to draw firm conclusions.

We analysed prognostic factors in 89 surgical cases with solitary or multiple parenchymal brain metastases and evaluated the outcome in relation to postoperative adjuvant treatment, preoperative and postoperative functional state, and the cause of death.

\section{Patients and methods}

This was an unselected retrospective series and the study comprised 89 patients who underwent surgical removal of solitary or multiple parenchymal brain metastases of lung cancer. These 89 patients were about $44 \%$ of the total number of patients with brain metastasis from lung cancer treated at our institution. They were treated at the Osaka Center for Adult Diseases between 1978 and 1990, and the study includes follow up data until 18 March 1992. Surgery was performed when prolongation of survival and improvement of the quality of life were expected, and one 
Table 1 Prognostic factors associated with the survival of patients with brain metastases from lung cancer

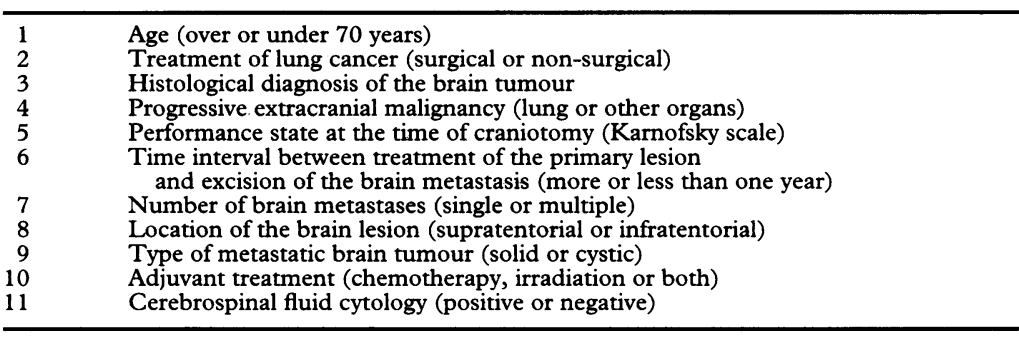

stage removal of single or multiple (up to three) tumours was possible. That is, patients selected for surgery were likely to either overtly or covertly have a better prognosis. Specific factors that might affect the prognosis (table 1) were evaluated in relation to the mean survival time (table 2) after brain tumour excision. The presence of tumours in other organs was assessed by chest radiographs, bone and tumour scintigraphy, ultrasonography, CT, and other examinations as necessary. Metastatic brain tumours that showed clear ring enhancement on CT and those containing more than $80 \%$ fluid were classified as cystic. Brain metastases from small cell lung cancer were usually treated by

Table 2 Relationships between prognostic factors and mean survival time

\begin{tabular}{|c|c|c|c|}
\hline Prognostic factor & $\begin{array}{l}\text { Survival } \\
\text { (days) }\end{array}$ & $\begin{array}{l}\text { No of } \\
\text { patients }\end{array}$ & p Value ${ }^{\star}$ \\
\hline \multicolumn{4}{|l|}{ Age: } \\
\hline$>70$ & $368(62)$ & 75 & \\
\hline$\leqslant 70$ & $294(67)$ & 14 & \\
\hline$>65$ & $408(76)$ & 56 & \\
\hline$\leqslant 65$ & $248(37)$ & 27 & \\
\hline \multirow{2}{*}{\multicolumn{4}{|c|}{$\begin{array}{l}\text { Lung cancer } \\
\text { treatment: }\end{array}$}} \\
\hline & & & \\
\hline Non-surgical & $225(52)$ & 38 & \\
\hline Surgical & $500(98)$ & 51 & $<0.005$ \\
\hline Stage 1 & $447(94)$ & 11 & \\
\hline Stage $>3$ & $297(41)$ & 24 & \\
\hline \multicolumn{4}{|l|}{$\begin{array}{l}\text { Histological } \\
\text { diagnosis of type }\end{array}$} \\
\hline \\
\hline Adenocarcinoma & $510(97)$ & 52 & \\
\hline Squamous cell & $205(32)$ & 17 & \\
\hline Small cell & $192(38)$ & 8 & $<0.05$ \\
\hline Large cell & $177(46)$ & 12 & \\
\hline \multicolumn{4}{|l|}{ Extracranial } \\
\hline \multicolumn{4}{|l|}{ tumour(s): } \\
\hline $\begin{array}{l}\text { Negative } \\
\text { Positive }\end{array}$ & $250(37)$ & 60 & $<0.05$ \\
\hline \multicolumn{4}{|l|}{ Preoperative } \\
\hline \multicolumn{4}{|l|}{$\begin{array}{l}\text { perrormance } \\
\text { state: }\end{array}$} \\
\hline $100-80 \%$ & $387(55)$ & 33 & \\
\hline $70-50 \%$ & $353(84)$ & 40 & $<0.005$ \\
\hline $40 \%$ & $161(27)$ & 16 & \\
\hline \multicolumn{4}{|l|}{ Interval from } \\
\hline \multicolumn{4}{|l|}{$\begin{array}{l}\text { treatment of } \\
\text { lung cancer to }\end{array}$} \\
\hline \multicolumn{4}{|l|}{$\begin{array}{l}\text { lung cancer to } \\
\text { brain surgery: }\end{array}$} \\
\hline$\geqslant 1$ year & $325(43)$ & 23 & \\
\hline$<1$ year & $376(73)$ & 60 & \\
\hline \multicolumn{4}{|l|}{ No of brain tumours: } \\
\hline One & $470(91)$ & 57 & \\
\hline Multiple & $232(30)$ & 32 & \\
\hline \multicolumn{4}{|l|}{ Site of brain tumours: } \\
\hline Supratentorial (one) & $494(99)$ & 52 & \\
\hline Infratentorial (one) & $215(57)$ & 5 & \\
\hline \multicolumn{4}{|l|}{ Type of brain tumour: } \\
\hline Solid & $380(66)$ & 75 & \\
\hline Cystic & $277(74)$ & 13 & \\
\hline \multicolumn{4}{|l|}{ Adjuvant treatment: } \\
\hline Yes & $437(82)$ & 63 & \\
\hline No & $250(73)$ & 26 & $<0.05$ \\
\hline \multicolumn{4}{|l|}{ CSF cytology: } \\
\hline Negative & $373(66)$ & 80 & \\
\hline Positive & $467(185)$ & 9 & \\
\hline
\end{tabular}

^ Kaplan-Meier method. Values are means (SEM). chemotherapy, radiotherapy, or both without surgery, although the histological diagnosis of small cell carcinoma was sometimes only established after removal of the tumour and such cases were included in our analysis. Chemotherapy and irradiation were given on a case to case basis, as there were no fixed criteria for adjuvant treatment. Whole brain irradiation ranging from 20 Gy (10 irradiation sessions with $2 \mathrm{~Gy} /$ day) over two weeks to 50 Gy (20 irradiation sessions with 2.5 Gy/day) over four weeks was performed. Chemotherapy was performed with either carcinostatic agents thought to be effective against the primary lesion or with nitrosourea drugs. In 25 patients, chemotherapy with cisdiaminedichloroplatinum (CDDP) was performed as a specific trial between 1988 and 1990 to evaluate its effectiveness. These data were published elsewhere. ${ }^{7}$ Briefly, during surgery, $100 \mathrm{mg} / \mathrm{sq} \mathrm{m}$ of CDDP was given intravenously or intra-arterially. During the first year after surgery, the patients were admitted to hospital every three months, or whenever possible, for intravenous administration of CDDP at the same dose $\left(100 \mathrm{mg} / \mathrm{m}^{2}\right)$. It was given $3 \cdot 2$ times to each patient on average. Radiotherapy was given to 11 randomly selected patients to evaluate the efficacy of chemotherapy alone and of chemotherapy combined with radiotherapy. The preoperative and postoperative functional state (Karnofsky score $^{8}$ ) were studied in relation to the survival time. The differences in mean survival time (Kaplan-Meier method) were compared in relation to each of the prognostic factors, and significant differences were determined by the generalised Wilcoxon test and the log rank test. Both tests were applied to between group differences and the log rank test was used for multiple group differences.

\section{Results}

The overall mean survival time was 11.6 months $(n=89)$. Forty eight patients $(54 \%)$ survived for six months or longer, 37 (42\%) for nine months or longer, $21(24 \%)$ for one year or longer, $12(13 \%)$ for 1.5 years or longer, and seven $(8 \%)$ for two years or longer.

\section{PROGNOSTIC FACTORS AND SURVIVAL TIME}

Age

The patients were divided into those aged 70 years or older at the time of detection of the metastatic brain tumour and those under 70 years of age. No significant difference in the duration of survival was noted between these two groups (fig 1), and this was also the case when the patients were divided into those aged 65 years or older, and those under 65 (table 2).

Surgical excision stage and curative nature of the primary lesion

A statistically significant difference was confirmed between the patients with and without lung cancer excision (table 2). The mean survival time was 358 days when excision of the 
Figure 1 Prognostic variables showing no statistically significant differences.
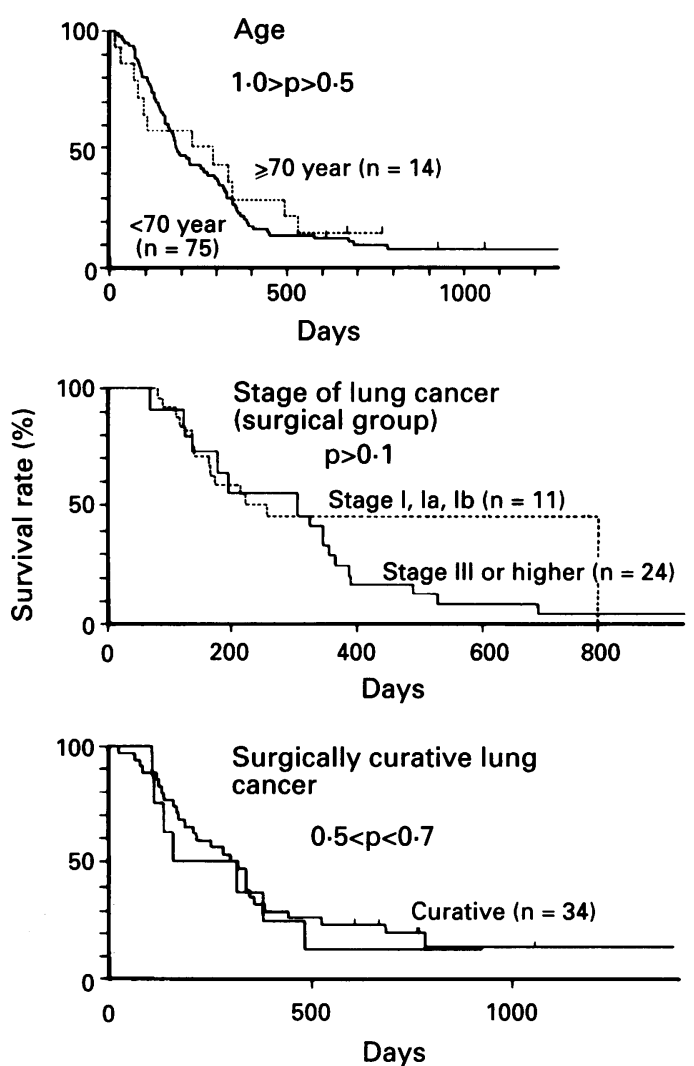

primary lung tumour was performed after surgery for the brain metastasis $(n=9)$ compared with 535 days when lung cancer surgery preceded brain surgery $(n=42)$. The mean survival time was 225 days for patients whose lung tumours were not surgically treated $(n=38)$.

Table 3 Survival in relation to the site(s) of extracranial tumours

\begin{tabular}{|c|c|c|c|}
\hline Extracranial lesions & $\begin{array}{l}\text { Survival } \\
\text { (days) }\end{array}$ & $\begin{array}{l}\text { No of } \\
\text { patients }\end{array}$ & $p$ Value * \\
\hline Tumours only in the lungs & $328(79)$ & 24 & \multirow{2}{*}{$<0.01$} \\
\hline $\begin{array}{l}\text { Tumours in the lungs } \\
\text { and other organs }\end{array}$ & $131(19)$ & $26 \int$ & \\
\hline $\begin{array}{l}\text { Tumour in the lungs with } \\
\text { or without tumours in } \\
\text { other organs }\end{array}$ & $225(41)$ & 507 & \multirow{2}{*}{$<0.05$} \\
\hline $\begin{array}{l}\text { Tumours in other organs } \\
\text { without any lung tumour }\end{array}$ & $375(58)$ & 10 & \\
\hline
\end{tabular}

Table 4 Correlations between adjuvant treatment and survival

\begin{tabular}{|c|c|c|c|}
\hline Treatment & $\begin{array}{l}\text { Survival } \\
\text { (days) }\end{array}$ & $\begin{array}{l}\text { No of } \\
\text { patients }\end{array}$ & p Value ${ }^{\star}$ \\
\hline $\begin{array}{l}\text { Radiotherapy: } \\
(+) \\
(-)\end{array}$ & $\begin{array}{l}243(29) \\
484(100)\end{array}$ & $\begin{array}{l}37 \\
52\end{array}$ & \\
\hline $\begin{array}{l}\text { Chemotherapy: } \\
(+) \\
(-)\end{array}$ & $\begin{array}{l}510(100) \\
219(50)\end{array}$ & $\begin{array}{l}50 \\
39\end{array}$ & $<0.005$ \\
\hline $\begin{array}{l}\text { Adjuvant treatment regimen: } \\
\text { a no adjuvant treatment } \\
\text { b chemotherapy alone } \\
\text { c radiotherapy alone } \\
\text { d irradiation }+ \\
\text { chemotherapy }\end{array}$ & $\begin{array}{l}250(73) \\
709(179) \\
157(27) \\
301(37)\end{array}$ & $\begin{array}{l}26 \\
27 \\
13 \\
\\
23\end{array}$ & $\begin{array}{l}<0.05(\mathrm{a} v \mathrm{~b}) \\
<0.05(\mathrm{~b} v \mathrm{c}) \\
<0.05(\mathrm{c} v \mathrm{~d})\end{array}$ \\
\hline
\end{tabular}

ॠ Kaplan-Meier method. Values are means (SEM).
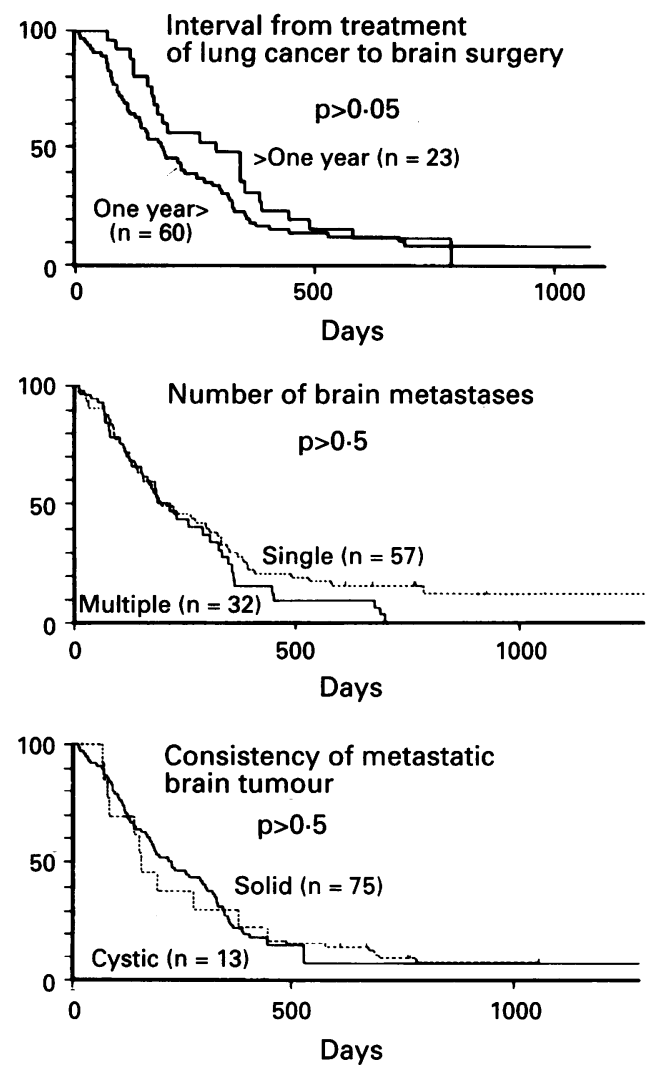

The lung cancers were staged at the time of pulmonary surgery in accordance with the UICC system (1978). Patients with stage 1 tumours survived longer than those whose tumours were stage 3 or higher, but the difference was not significant (table 2, fig 1). There was also no significant difference in mean survival time between curative and noncurative lung surgery (fig 1).

\section{Histological diagnosis}

Adenocarcinoma was associated with a significantly longer survival than the other three histological types of metastatic brain tumour (table 2, fig 2).

\section{Presence of extracranial tumours at the time of} neurosurgery

A significantly shorter survival was noted in patients with documented extracranial metastases at the time of neurosurgery compared with those without such metastases (patients in whom the brain was the first site of metastasis) (table 2, fig 2). Among the patients with extracranial tumours, the mean survival time was significantly longer if the tumour was outside the lungs than if a lung lesion was present (table 3).

\section{Preoperative performance state}

The patients were divided into three groups according to their preoperative Karnofsky scores: $100-80 \%, 70-50 \%$, and $40 \%$ or lower. There was a significant difference in mean survival time between each group, and the patients with scores of $100-80 \%$ had the longest mean survival time (table 2, fig 2 ). 
Figure 2 Prognostic variables showing statistically significant differences.
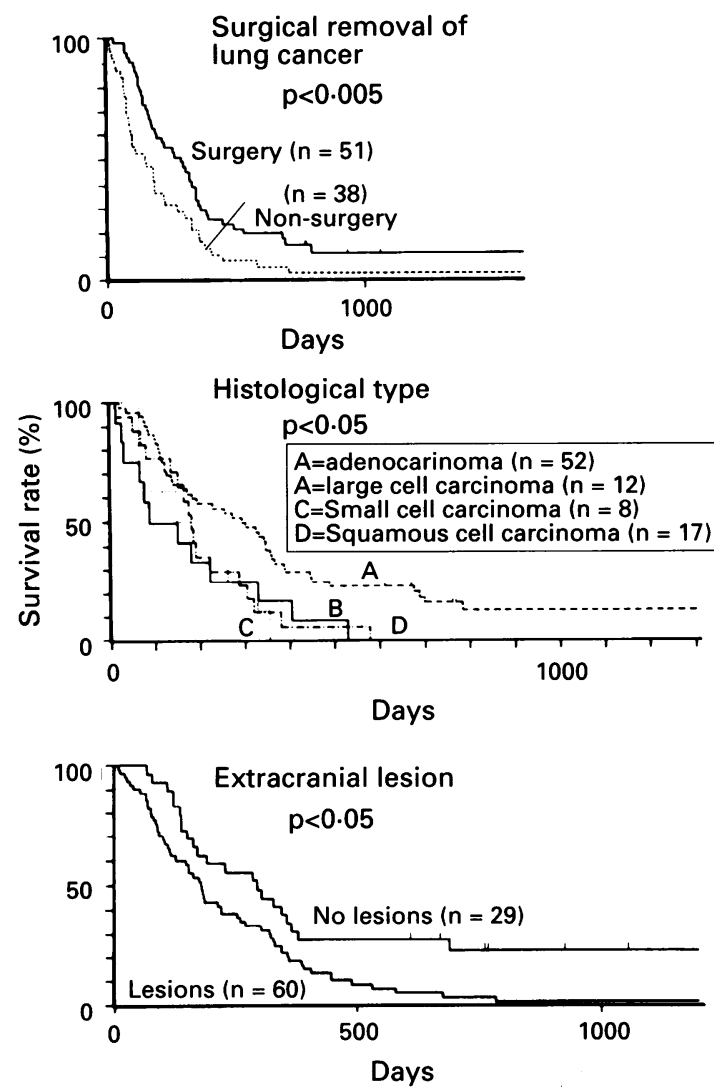

Interval between treatment of the primary lesion and excision of brain metastases

No difference in mean survival time was found between patients with an interval from treatment of lung cancer to neurosurgery of less than one year and those for whom the interval was more than one year (table 2, fig 1).

Number, type, and location of brain metastases The mean survival time was longer in patients with a solitary brain metastasis than in those with multiple metastases, but the difference was not significant (table 2, fig 1). Solid tumours were associated with a longer mean survival time than cystic tumours (table 2, fig 1). The outcome was better for solitary supratentorial metastases than solitary infratentorial tumours (table 2), but neither of these differences was significant.

Adjuvant treatment

A significantly longer survival was found in the patients who received adjuvant treatment than
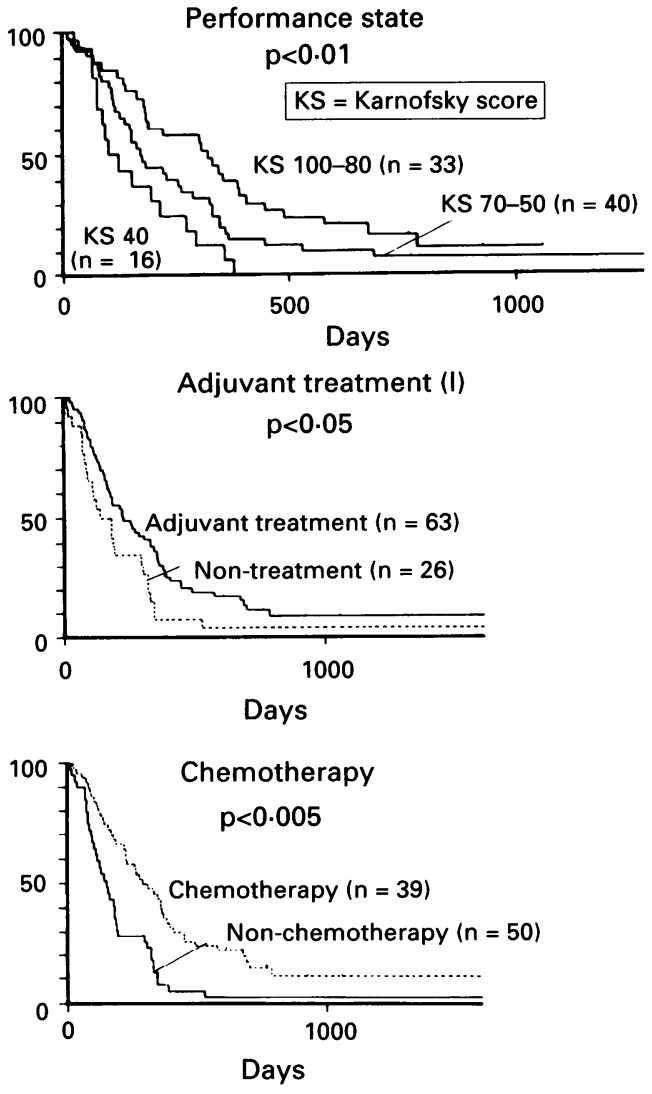

in those who did not (tables 2 and 4, fig 2). Although radiotherapy had no significant effect on the mean survival time, chemotherapy significantly prolonged it, and the combination of chemotherapy and radiotherapy was significantly more effective than radiotherapy alone. The mean survival time of patients who received chemotherapy alone was also longer than that of patients who underwent surgery and received no adjuvant therapy (table 4).

For further analysis, the chemotherapy regimens were divided into those involving CDDP, nitrosoureas (ACNU or methyl-CCNU), and other anticancer agents (cyclophosphamide, vincristine, methotrexate, 5-fluorouracil, tegafur, mitomycin-C, and doxorubicin). Nitrosourea agents produced a considerable variation in response and there was a large standard error. Patients given CDDP had a significantly longer mean survival time than patients given other anticancer agents, but there were no other significant differences in terms of the specific agents given (table 5). Among those receiving chemotherapy alone, four patients in the CDDP group showed

Table 6 Preoperative and postoperative performance state according to Karnofsky scale score

\begin{tabular}{llccl}
\hline \multirow{2}{*}{$\begin{array}{l}\text { Postoperative } \\
\text { score }\end{array}$} & \multicolumn{4}{l}{ Preoperative score } \\
\cline { 2 - 5 } & $30-40$ & $50-60$ & $70-80$ & $90-100$ \\
\hline $30-40$ & 7 & 3 & 0 & 1 \\
$50-60$ & 4 & 11 & 0 & 1 \\
$70-80$ & 2 & 6 & 24 & 2 \\
$90-100$ & 2 & 1 & 7 & 7 \\
\hline
\end{tabular}

Improved 32 cases; stable 47 ; deteriorated 10; improvement due to surgery: performance state improved in 13 of 56 cases from lower than to higher than $80 \%$ on the Karnofsky scale score. 
Table 7 Review of the medical literature on prognostic factors associated with survival in patients with metastatic brain tumour

\begin{tabular}{|c|c|c|c|}
\hline $\begin{array}{l}\text { Authors } \\
\text { (total number } \\
\text { of patients) }\end{array}$ & Year & $\begin{array}{l}\text { Primary cancer; } \\
\text { (surgical case) }\end{array}$ & Prognostic factors \\
\hline $\begin{array}{l}\text { DiStefano et } a l^{5} \\
\quad(101)\end{array}$ & 1979 & $\begin{array}{r}\text { Breast cancer } \\
\quad(\text { solitary } 7)\end{array}$ & $\begin{array}{l}\text { Brain as initial site of metastasis } \\
\text { Tumour free interval } \\
\text { Resection of brain metastasis }\end{array}$ \\
\hline $\begin{array}{l}\text { Galicich et } a l^{20} \\
\quad(78)\end{array}$ & 1980 & $\begin{array}{l}\text { All cancers } \\
\quad(\text { solitary 78) }\end{array}$ & $\begin{array}{l}\text { Tumour free interval } \\
\text { Preoperative performance state }\end{array}$ \\
\hline $\begin{array}{l}\text { Winston et al } \\
\quad(79)\end{array}$ & 1980 & $\begin{array}{l}\text { All cancers } \\
\text { (solitary 73, } \\
\text { multiple 6) }\end{array}$ & Primary tumour \\
\hline $\begin{array}{l}\text { White et al }{ }^{10} \\
\quad(122)\end{array}$ & 1981 & $\begin{array}{l}\text { All cancers } \\
\quad(\text { solitary } 122)\end{array}$ & $\begin{array}{l}\text { Location } \\
\text { Extent of tumour removal } \\
\text { Tissue of origin } \\
\text { Age and sex } \\
\text { Tumour free interval }\end{array}$ \\
\hline$\underset{(191)}{\operatorname{Zimm} e t} a{ }_{,}^{11}$ & 1981 & $\begin{array}{l}\text { All cancers } \\
\text { (solitary 24, } \\
\text { multiple 5) }\end{array}$ & $\begin{array}{l}\text { Solitary tumour } \\
\text { Brain as initial site of metastasis } \\
\text { Preoperative performance state } \\
\text { Age } \\
\text { Extent of tumour removal }\end{array}$ \\
\hline $\begin{array}{l}\text { Chan and Steinbok }{ }^{17} \\
(57)\end{array}$ & 1982 & $\begin{array}{l}\text { All cancers } \\
\quad \text { (solitary 57) }\end{array}$ & $\begin{array}{l}\text { Solitary tumour } \\
\text { Tumour free interval } \\
\text { Presence of systemic metastases } \\
\text { Site of primary tumour }\end{array}$ \\
\hline $\begin{array}{l}\text { Robin et } a l^{18} \\
\quad(38)\end{array}$ & 1982 & $\begin{array}{l}\text { Lung cancer } \\
\text { (non-small cell) } \\
\text { (non-surgery) }\end{array}$ & $\begin{array}{l}\text { Response to total treatment } \\
\text { No extracranial lesions }\end{array}$ \\
\hline $\begin{array}{l}\text { Sundaresan et al }{ }^{14} \\
\text { (35) }\end{array}$ & 1983 & $\begin{array}{l}\text { Lung cancer } \\
\text { (non-small cell) } \\
\text { (solitary 34, } \\
\text { double 1) }\end{array}$ & $\begin{array}{l}\text { Presence of local or } \\
\text { systemic disease } \\
\text { Aggressive treatment } \\
\text { of primary tumour } \\
\text { Metachronous onset } \\
\text { of brain metastasis }\end{array}$ \\
\hline $\begin{array}{l}\text { Yardeni et } a l^{21} \\
\quad(74)\end{array}$ & 1984 & $\begin{array}{l}\text { All cancers; } \\
\quad(\text { solitary } 74)\end{array}$ & $\begin{array}{l}\text { Solitary tumour } \\
\text { Tumour free interval } \\
\text { Location of brain metastasis }\end{array}$ \\
\hline $\begin{array}{l}\text { Sundaresan et al }{ }^{19} \\
\quad(125)\end{array}$ & 1985 & $\begin{array}{l}\text { All cancers; } \\
\text { (solitary 119, } \\
\text { multiple 6) }\end{array}$ & $\begin{array}{l}\text { Site of primary tumour } \\
\text { Location of brain metastasis } \\
\text { Extent of systemic disease } \\
\text { Preoperative performance state }\end{array}$ \\
\hline $\begin{array}{l}\text { Pellettieri et } a l^{9} \\
\quad(134)\end{array}$ & 1987 & $\begin{array}{l}\text { All cancers; } \\
\text { (solitary 134) }\end{array}$ & $\begin{array}{l}\text { Histological diagnosis } \\
\text { Location of brain metastasis } \\
\text { State on admission } \\
\text { Age }\end{array}$ \\
\hline $\begin{array}{l}\text { Pladdet et al }{ }^{16} \\
\quad(214)\end{array}$ & 1989 & $\begin{array}{l}\text { All cancers } \\
\text { (solitary 38) }\end{array}$ & $\begin{array}{l}\text { Solitary tumour } \\
\text { Presence of extracranial tumours } \\
\text { Resection of brain metastasis }\end{array}$ \\
\hline $\begin{array}{l}\text { Nakagawa et al } \\
\text { (present case) } \\
\quad(89)\end{array}$ & 1992 & $\begin{array}{l}\text { Lung cancer } \\
\text { (solitary 57, } \\
\text { multiple* 32) }\end{array}$ & $\begin{array}{l}\text { Excision of lung tumour } \\
\text { Histological diagnosis } \\
\text { Presence of extracranial tumours } \\
\text { Preoperative performance state } \\
\text { Adjuvant treatment }\end{array}$ \\
\hline
\end{tabular}

* Up to three tumours.
Karnofsky scores before and after surgery

Thirty two of the 89 patients $(36 \%)$ had an improved score after surgery, 47 (53\%) showed no change, and the score decreased in 10 cases $(11 \%)$. Five patients had a postoperative Karnofsky score of $100 \%$ (including one whose preoperative score was $100 \%$ ) and 43 patients $(48 \%)$ had a postoperative score of $80 \%$. Of the 56 patients with operative scores below $80 \%, 13$ improved to $80 \%$ after surgery (table 6).

\section{Discussion}

There have been numerous reports concerning the factors influencing the prognosis of metastatic brain tumours (table 7). Our results indicate that the type of tumour (solid or cystic) is a prognostic factor, as there was a trend toward a worse prognosis for cystic tumours. In these patients, multiple brain metastases and subdural tumours tended to develop soon after neurosurgery, suggesting that dissemination of tumour cells occurred through cystic fluid escape during surgery. In this context, CSF cytology also seems to provide important data. Such cytology was not, however, a significant factor in the present study.

Various authors ${ }^{9-11}$ have reported that the prognosis worsens with advancing age. This is believed to be due to physical frailty and reduced tolerance of the brain to radiation and chemotherapy. This finding was not supported in our analysis with cut off points of either 65 or 70 years of age.

In terms of the histological type of lung cancer, the prognosis is best for adenocarcinoma, followed in descending order by squamous cell carcinoma, large cell carcinoma, and small cell carcinoma (the prognosis is particularly poor for small cell carcinoma). The reported frequency of brain metastases is greatest for large cell carcinoma, followed by small cell carcinoma, adenocarcinoma, and squamous cell carcinoma. ${ }^{12}$ In our study, as in others, the outcome for brain metastases from adenocarcinoma was relatively good, whereas that for large cell carcinoma was poor.

The prognosis of patients with lung cancer and brain metastases is usually poor, and the estimated median survival is only one to six months in the presence of an active lesion in the lung. It has been reported that surgical removal of both the brain metastasis and the lung lesion yields a better prognosis. ${ }^{13} 15$ In the present study, survival was longer when the primary lesion was surgically removed than when it was treated conservatively, regardless of whether its removal preceded or followed excision of the metastatic brain tumour. Although brain metastases may recur even after excision of the primary lesion, it seems that absence of the primary tumour improves the clinical course after removal of the metastases. Zimm et $a l^{11}$ and Pladdet et $a l^{16}$ reported that the prognosis was good when there were no metastases to organs other than the brain, and our findings supported this conclusion. Many other authors have cited the absence of primary and metastatic 
tumours outside the brain as a favourable prognostic factor. ${ }^{14-19}$ Our data suggest that not only is the prognosis significantly poorer if any extracranial lesions are present, but also that the prognosis is significantly further worsened by the presence of tumour in the lungs, as opposed to other organs.

Many investigators have discussed preoperative functional state as a factor influencing prognosis. ${ }^{111920}$ We also found a significant difference between patients with higher and lower Karnofsky scores, particularly those with scores below $40 \%$ and above $80 \%$.

Zimm et al, ${ }^{11}$ Yardeni et $a l,{ }^{21}$ and many other authors 510172022 have reported that the prognosis improves as the interval between the treatment of the primary lesion and the surgical removal of brain metastases becomes longer. This was not confirmed in our present study.

A single brain metastasis, as opposed to multiple lesions, is widely considered to be a favourable prognostic factor, and patients with a solitary brain metastasis are though to be the best candidates for surgery. Few reports are available concerning the surgical treatment of multiple brain metastases, and there have been no previous studies on the prognosis after the excision of such metastases. We found no significant differences in survival after the surgical removal of single metastases $(n=57$, mean survival time $=470$ days) and multiple ( $n=32$, mean survival time $=232$ days) metastases. Our patients with multiple metastases had been carefully selected by the number and location of the lesions, however, as well as their general condition. The lack of a significant difference between the two groups may also be due to advances in CT and ultrasonic diagnosis, which allow the accurate identification of small tumours, and to advances in surgical techniques that have made it possible to remove small and deeply situated tumours. Furthermore, the survival of a few patients with multiple metastatic brain tumours was possibly prolonged by aggressive chemotherapy or radiotherapy, plus intrathecal chemotherapy when meningeal carcinomatosis developed after tumour removal.

Several investigators have asserted that the prognosis is worse for infratentorial tumours than for supratentorial tumours, due to the inaccessibility of lesions in the posterior cranial fossa or in regions outside the brainstem. ${ }^{9192123}$ When such tumours enlarge and seed the cerebrospinal fluid, metastasis is facilitated and the lesion rapidly becomes inoperable when it extends further into the brainstem.

Our findings showed that there was a trend toward a worse prognosis for cystic tumours than for solid tumours. This may indicate that cystic tumour is a factor in poor prognosis. The current surgical procedure for cystic tumours in our institution is to completely aspirate the cyst fluid in an attempt to prevent tumour dissemination, and then to pack the tumour cavity with cotton to maintain pressure on the cyst wall during its excision, thus reducing the chance that part of the tumour will be left behind. Although we cannot conclusively state that the better results found in recent cases are directly attributable to this technique, the outcome of such patients has indeed improved.

In a study involving non-surgical cases, Robin et al ${ }^{18}$ found that the response to nonsurgical treatment is an important factor in the prognosis of patients with metastatic brain tumours. We found the mean survival time to be significantly shorter in surgical patients who were not given adjuvant treatment. In our opinion, adjuvant treatment should generally follow excision of brain metastases, especially considering that metastatic lesions smaller than $1.0 \mathrm{~cm}$ which are not seen on CT can often be shown by MRI postoperatively.

Opinions differ regarding chemotherapy for metastatic brain tumours. We have noted that radiation insensitive tumours may disappear on MRI after combined chemotherapy and irradiation due to enhancement of the radiation effect by chemotherapy. We also sometimes found a heightened response to chemotherapy after radiotherapy, which is probably due to increased tumour penetration by the chemotherapeutic agents as a result of modifications in the capillary endothelium due to irradiation. For these reasons, we are apt to use combined chemotherapy and radiotherapy. Survival time was not increased in the group receiving radiotherapy alone or those receiving chemotherapy plus radiotherapy, however, in comparison with that of the group receiving no adjuvant treatment in the present study. Survival was significantly prolonged in the group receiving combined chemotherapy and irradiation compared with that in the group receiving irradiation alone. There are several probable reasons why radiotherapy had the opposite effect to that expected in patients with brain metastases. Firstly, in the group receiving radiation therapy alone and those receiving chemotherapy plus radiotherapy, cancer lesions outside the brain were not well controlled and patients in those groups died from cancer in other organ(s) even though brain metastases were controlled. Secondly, intentional selection of the treatment regimen was a possibility. That is, there was a tendency for patients who were in better condition to refuse radiotherapy and chemotherapy, whereas radiotherapy alone was selected for patients in the worst condition. Moreover, prolonged survivals among patients receiving CDDP and nitrosourea led to the longer mean survival among patients receiving chemotherapy alone compared with that of those receiving chemotherapy plus radiotherapy. As for the effect of CDDP on lung cancer, antagonistic views have been reported. ${ }^{24-27}$ We tried to evaluate the effects of CDDP on brain tumours from lung cancer and found a significantly higher two year survival rate and longer mean interval from resection of the metastatic brain tumour to local or remote recurrence than those in the two groups treated with other drugs and those who received no chemotherapy. ${ }^{7}$ 
Opinions also differ as to whether it is better to use a carcinostatic agent to which the primary lesion is sensitive, or to use a lipid soluble nitrosourea that can cross the blood brain barrier. As this barrier already seems to be partially disrupted in patients with metastatic brain tumours, it has been reported that drugs that are effective against the primary lesion are also effective against brain metastases. ${ }^{28} 29$ Therefore, most clinicians advocate the use of carcinostatic agents. ${ }^{30}$ Surgical specimens sometimes show tumour cell nests in the surrounding brain parenchyma where the bloodbrain barrier is presumably still intact, and we have encountered postoperative tumour recurrence in the surgical cavity. These experiences led us to use nitrosourea agents, but we found that the response to these drugs varied considerably (table 5).

In summary, the significant prognostic factors were mode of treatment of the lung cancer, histology of the brain metastases, the presence or absence of extracranial tumour, the preoperative performance state, and the use and type of adjuvant treatment. Surgical excision of the lung tumour, a diagnosis of adenocarcinoma, metastases confined to the brain with no carcinoma confirmed in any other organ, a Karnofsky score greater than $80 \%$, and the use of adjuvant treatment (especially chemotherapy) were the major favourable prognostic factors. The patient's age, the stage of the lung cancer at the time of surgery, the number and location (supratentorial or infratentorial) of the intracranial metastases, and type of metastatic brain tumour (solid or cystic) may also affect the prognosis, although a significant influence was not confirmed in the present study.

When the benefit of surgery was evaluated in terms of changes in functional state, $36 \%$ of the patients improved, $53 \%$ showed no change, and only $11 \%$ deteriorated. These results are somewhat better than those obtained by Sundaresan et al $^{14} ; 75 \%$ of their patients improved or were the same after surgery. It is possible that these results are related to recent advances in CT and other diagnostic imaging techniques, including the ability to perform intraoperative ultrasonography of the brain surface. These techniques facilitate the detection of deep brain tumours and permit surgical removal with less damage to normal brain tissue. Even in patients with multiple tumours, surgical excision generally improved, or at least did not worsen their neurological state. Our analysis of the cause of death implicated the brain lesions in only $19 \%$ of the patients. This figure is low compared with the results given in other reports, ${ }^{511}$ and may be credited to aggressive surgery followed by adjuvant treatment.

In summary, this retrospective analysis of 89 surgical cases indicates that improved survival of patients with brain metastases of lung cancer can be achieved by surgical resection of the metastatic lesions followed by appropriate chemotherapy, provided that the primary lung tumour has already been resected.
1 Gelber RD, Larson M, Borgelt BB, Kramer S. Equivalence of radiation schedules for the palliative treatment of brain metastases in patients with favorable prognosis. Cancer 1981;48:1949-53.

2 Black P. Brain metastasis: current status and recommended guidelines for management. Neurosurgery 1979; 5:617-31.

3 Ransohoff J. Surgical management of metastatic tumors. Semin Oncol 1975;2:21-7.

4 Patchell RA, Tibbs PA, Walsh JW, et al. A randomized trial of surgery in the treatment of single metastases to the brain. N Engl f Med 1990;322:494-500.

5 DiStefano A, Yap HY, Hortobagyi GN, Blumenschein GR. The natural history of breast cancer patients with brain metastases. Cancer 1979;44:1913-8.

6 Sarma DP, Weilbaecher TG. Long-term survival after brain metastasis from lung cancer. Cancer 1986;58: 1366-70.

7 Nakagawa $H$, Fujita $T$, Izumoto $S$, et al. Cisdiaminedichloroplatinum (CDDP) therapy for brain metastasis of lung cancer. II: Clinical effects. F Neurooncol 1993; 16:69-76.

8 Karnofsky DA, Burchenal JH. The clinical evaluation of chemotherapeutic agents in cancer. In: MacLeod CM, ed. Evaluation of chemotherapeutic agents New York: ed. Evaluation of chemotherapeutic agents

9 Pellettieri L, Sjolander U, Jakobsson KE. Prognostic evaluation before operative extirpation and radiotherapy of solitary brain metastasis. Acta Neurochir (Wien) 1987; 86:6-11.

10 White KT, Fleming TR, Laws ER. Single metastasis to the brain: surgical treatment in 122 consecutive patients. Mayo Clin Proc 1981;56:424-8.

11 Zimm S, Wampler GL, Stablein D, Hazra T, Young HF Intracerebral metastases in solid-tumor patier ' natural history and results of treatment. Cancer i $981 ; 48$ : 384-94.

12 Yoshimura K. A clinical statistical analysis of 4931 lung cancer cases in Japan according to histological type-field study results: a report from the Japanese Joint Committee of lung cancer associated with the TNM system of clinical classification (UICC). Radiat Med 1984; tem of clin $237-51$.

13 Mussi A, Janni A, Pistolesi M, Ravelli V, Buonaguidi R, Angeletti CA. Surgical treatment of primary lung cance and solitary brain metastasis. Thorax 1985;40:191-3.

14 Sundaresan N, Galicich JH, Beattie EJ Jr. Surgical treatment of brain metastases from lung cancer. $\mathcal{F}$ Neurosurg 1983;58:666-71.

15 Torre M, Quaini E, Chiesa G, Ravini M, Soresi E, Belloni PA. Synchronous brain metastasis from lung cancer result of surgical treatment in combined resection. $f$ Thorac Cardiovasc Surg 1988;95:994-7.

16 Pladdet I, Boven E, Nauta J, Pinedo HM. Palliative care for brain metastases of solid tumour types. Neth $7 \mathrm{Med}$ 1989;34:10-21.

17 Chan R, Steinbok P. Solitary cerebral metastasis: the effect of craniotomy on the quality and duration of survival. Neurosurgery 1982;11:254-7.

18 Robin E, Bitran JD, Golomb HM, et al. Prognostic factors in patients with non-small cell bronchogenic carcinom in patients with non-small cell bronchogenic carc

19 Sundaresan N, Galicich JH. Surgical treatment of brain metastases: clinical and computed tomography evaluation of the results of treatment. Cancer 1985;55:1382-8.

20 Galicich JH, Sundaresan N, Arbit E, Passe S. Surgical treatment of single brain metastasis: factors associated with survival. Cancer 1980;45:381-6.

21 Yardeni D, Reichenthal E, Zucker G, et al. Neurosurgical management of single brain metastasis. Surg Neurol 1984;21:377-84.

22 Macchiarini P, Buonaguidi $R$, Hardin $M$, Mussi A, Angeletti CA. Results and prognostic factors of surgery in the management of non-small cell lung cancer with solitary brain metastasis. Cancer 1991;68:300-4.

23 Winston KR, Walsh JW, Fischer EG. Results of operative treatment of intracranial metastatic tumors. Cancer treatment of intract

24 Vogl SE, Berenzweig M, Camacho F, Greenwald E, Kaplan BH. Efficacy study of intensive cis-platin therapy Kaplan BH. Efficacy study of intensive cis-platin therapy
in advanced non-small cell bronchogenic carcinoma. in advanced non-small

25 De Jager R, Longeval E, Klastersky J. High-dose cisplatin with fluid and mannitol-induced diuresis in advanced lung cancer: a phase II clinical trial of the EORTC lung cancer working party (Belgium). Cancer Treat Rep 1980 64:1341-6.

26 Bhuchar VK, Lanzotti VJ. High-dose cisplatin for lung cancer. Cancer Treat Rep 1982;66:375-6.

27 Casper ES, Gralla RJ, Kelsen DP, Cvitkovic E, Golbey RB. Phase II study of high-dose cis-dichlorodiamineplatinum (II) in the treatment of non-small cell lung cancer. Cancer Treat Rep 1979;63: 2107-9.

28 Rosner D, Nemoto T, Pickren J, Lane W. Management of brain metastases from breast cancer by combination chemotherapy. $₹$ Neurooncol $1983 ; 1: 131-7$.

29 Rosner D, Nemoto T, Lane W. Chemotherapy induces regression of brain metastases in breast carcinoma. regression of brain mer 1986;58:832-9.

30 Vick NA, Khandekar LD, Bigner DD. Chemotherapy of brain tumors: the blood-brain barrier is not a factor. brain tumors: the blood-brain
Arch Neurol 1977;34:523-6. 